\title{
Fishing Ground Mapping Based on Chlorophyll-A Distribution Using Aqua Modis Satellite Imagery in The Fisheries Management Area (FMA) 712
}

\author{
Yulius Yulius $^{1 *}$,Vaninda Aidina ${ }^{2}$, Muhammad Ramdhan ${ }^{1}$, August Daulat ${ }^{1}$ \\ ${ }^{1}$ Agency for Marine and Fisheries Research, Ministry of Marine Affairs and Fisheries \\ ${ }^{2}$ Capture Fisheries Department, Faculty of Marine Science and Fisheries Diponegoro University
}

\begin{abstract}
The fishing ground is identical and closely related to chlorophyll-a abundance in the waters, associated with its fisheries potential. This research has been conducted to determine the concentration and distribution of chlorophyll-a in the seas, especially in the Fisheries Management Area (FMA) 712 encompassing the Java Sea. The analysis used monthly time-series data collected from the satellite imagery over the last 11 years, taken through the ERDDAP website. The mean concentration of chlorophyll-a in the study area was $1.13 \mathrm{mg} / \mathrm{l}$ in June 2013. Based on 11 years of data processing, it can be concluded that the highest concentration of chlorophyll-a occurred in the west monsoon season from November to April, where increased rainfall caused the nutrient wash from terrestrial to the open waters. The lowest chlorophyll-a concentration happened in the east monsoon season from April to November, where the dry season arrived. The existence of pelagic fishes in FMA 712, such as Sardinella Lemurs and Sardinella Fimbriata, in waters highly influenced by the chlorophyll-a concentration, while Thunnus Sp. and Exocoetidae Sp. not affected significantly to the existence of chlorophyll-a concentration and its distribution.
\end{abstract}

Keywords: Chlorophyll-a, FMA 712, Java Sea, pelagic fish

\section{Introduction}

Indonesia is an archipelagic country with a vast natural resources area with high potency and diverse biological natural resources. If adequately and appropriately managed, it can benefit the welfare of Indonesia, mainly fishermen [1]. Fisheries Management Area (FMA) is an operational area for managing and utilizing the fisheries sector potency in Indonesian waters. FMA 712 covers the Java Sea area, which has enormous capture fisheries potency, especially maratime. Indonesian fishing activities in FMA 712, particularly in the Java Sea, are concentrated on the north coast of Java [2]. However, the Ministry of Marine Affairs and Fisheries [3] found that the condition of fisheries natural resources in FMA 712 has been considered overexploited and overfished based on pressure from small fisheries vessels in the coastal region [4].

The presence of chlorophyll-a concentration is strongly influenced by several factors such as seasonal changes, which significantly affect anthropogenic movement from the terrestrial and its environment [5] and other factors such as oceanographic characteristics (tidal, current, turbidity, and dissolved oxygen) [6]. Upwelling phenomenon where the water column movement to the surface layer with high nutrition occurred over Java-Bali sea and its surroundings [7] also considered influencing chlorophylla fluctuation.

Mapping using Geographic Information Systems (GIS), more commonly referred to as remote sensing, is an accessible communication technology often used, especially in research activities [8]. Remote sensing is a communication mechanism from a distance where we can obtain data, information, analyze space and time, and translate an event without having direct contact with space and time. Remote sensing technology utilizing data from satellite imagery can be used to detect the presence of chlorophyll-a and analyze its abundance in water [9]. One of the satellite images often used for chlorophyll-a detection is the Aqua MODIS satellite image [10], where the interpretation of the satellite can determine the concentration of chlorophyll-a and the distribution of Sea Surface Temperature (SST) in the Java Sea waters. This study aims to determine the distribution and abundance of chlorophyll-a correlated with the fishing ground. This method can predict the fishing ground and assist fishers in effective and efficient fishing practice in terms of time, cost and logistics.

\section{Methods}

The research study located in the Java Sea waters at longitude $106^{\circ}$ East $-116^{\circ}$ East and latitude $3^{\circ}$ East $-7^{\circ}$ East. The data used for this study encompass monthly

\footnotetext{
* Corresponding author: yulius.lpsdkp@gmail.com
} 
average data of chlorophyll-a level 3 from Aqua MODIS satellite images with a resolution of $4 \mathrm{~km}$ [10] for 11 years taken from 2008 to 2018. Chlorophyll-a data processed using ArcGIS 10.3 software combined with Microsoft Excel for data processing and interpretation of chlorophyll-a changes over time using images and spatial distribution. The chlorophyll-a distribution map

was generated and used for fishing ground analysis to predict the potential area of capture fisheries for the fisherman based on space and time.

\section{Results and Discussion 3.1 Study Area}

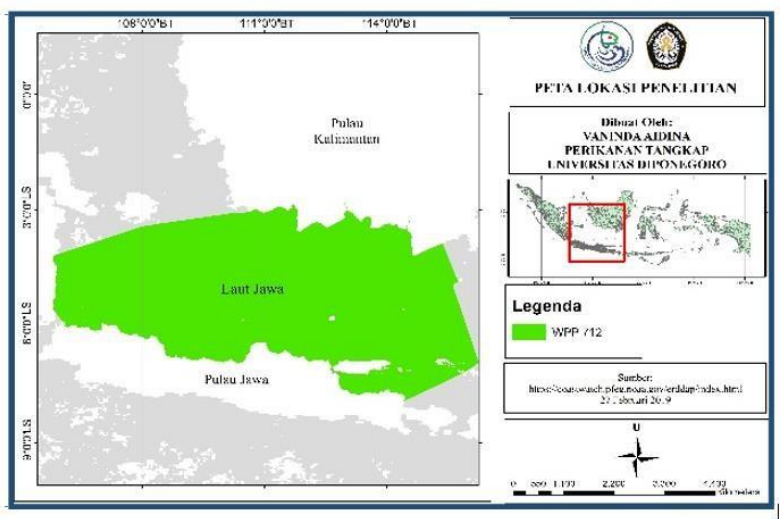

Figure 1. Study Site

Prediction of the potential fishing ground is an essential exploration activity in terms of utilization, administration, and management of unique conservation natural resources in the fisheries world [11]. FMA 712 encompass the Java Sea, which is administratively located in the north, adjacent to several provinces in Borneo such as West Borneo Province, Central Borneo Province, and South Borneo Province, while in the south bordering Java Island, which includes Banten Province, West Java Province, DKI Jakarta Province, Central Java Province, and East Java Province.

The monsoon wind movement, as a unique characteristic of Indonesian climate, causes variations in surface temperature in Indonesian waters, the especially the Java Sea [7], where during the southeast monsoon period, (east monsoon) winds and currents in the Java Sea move from the east to the west bringing relatively more relaxed water mass into the west, as shown by the isotherm line pattern formed in the western part of the Java Sea [6].

\subsection{Changes in Chlorophyll-a Concentration}

Chlorophyll-a is one of the pigments contained in phytoplankton that plays a role in the photosynthesis process, which can be used as an indicator of water quality and fertility in a region based on its concentration [12]. The distribution of chlorophyll-a concentrations is closely related to the oceanographic conditions of water. Distribution and concentration of chlorophyll-a combined with remote sensing technique using particular satellite images can predict the abundance of phytoplankton associated with the fishing ground [9].
Table 1. Average chlorophyll-a concentration 2008-2018

\begin{tabular}{|l|c|c|c|c|c|c|c|c|c|c|c|c|}
\hline Year & Jan & Feb & Mar & April & May & June & July & Aug & Sept & Oct & Nov & Des \\
\hline 2008 & 1.10 & 2.35 & 1.04 & 0.89 & 0.93 & 0.92 & 0.79 & 0.69 & 0.83 & 0.74 & 1.10 & 0.96 \\
\hline 2009 & 1.03 & 1.18 & 0.94 & 1.10 & 1.05 & 0.85 & 0.80 & 0.62 & 0.52 & 0.76 & 0.66 & 1.00 \\
\hline 2010 & 1.70 & 1.32 & 1.11 & 1.29 & 1.35 & 1.23 & 1.16 & 1.07 & 1.05 & 1.10 & 0.79 & 2.42 \\
\hline 2011 & 2.37 & 1.25 & 1.19 & 1.10 & 1.00 & 0.84 & 0.74 & 0.65 & 0.59 & 0.60 & 0.84 & 1.02 \\
\hline 2012 & 1.20 & 1.16 & 0.69 & 1.02 & 1.03 & 0.86 & 0.78 & 0.69 & 0.51 & 0.48 & 0.73 & 0.85 \\
\hline 2013 & 1.86 & 0.86 & 0.91 & 1.04 & 1.07 & 1.13 & 1.02 & 0.79 & 0.55 & 0.49 & 1.11 & 1.14 \\
\hline 2014 & 1.63 & 1.13 & 1.04 & 0.95 & 1.10 & 1.00 & 0.81 & 0.74 & 0.63 & 0.46 & 0.56 & 1.44 \\
\hline 2015 & 1.14 & 1.83 & 1.60 & 1.51 & 1.31 & 1.03 & 0.78 & 0.68 & 0.53 & 0.40 & 0.50 & 0.85 \\
\hline 2016 & 0.90 & 0.98 & 0.88 & 1.11 & 1.05 & 1.05 & 0.91 & 0.85 & 0.63 & 0.67 & 1.42 & 2.29 \\
\hline 2017 & 1.15 & 1.20 & 0.83 & 0.92 & 1.09 & 0.98 & 0.91 & 0.82 & 0.84 & 0.88 & 1.31 & 1.28 \\
\hline 2018 & 0.98 & 1.06 & 0.85 & 0.99 & 0.87 & 0.80 & 0.67 & 0.61 & 0.54 & 0.40 & 0.56 & 0.99 \\
\hline
\end{tabular}

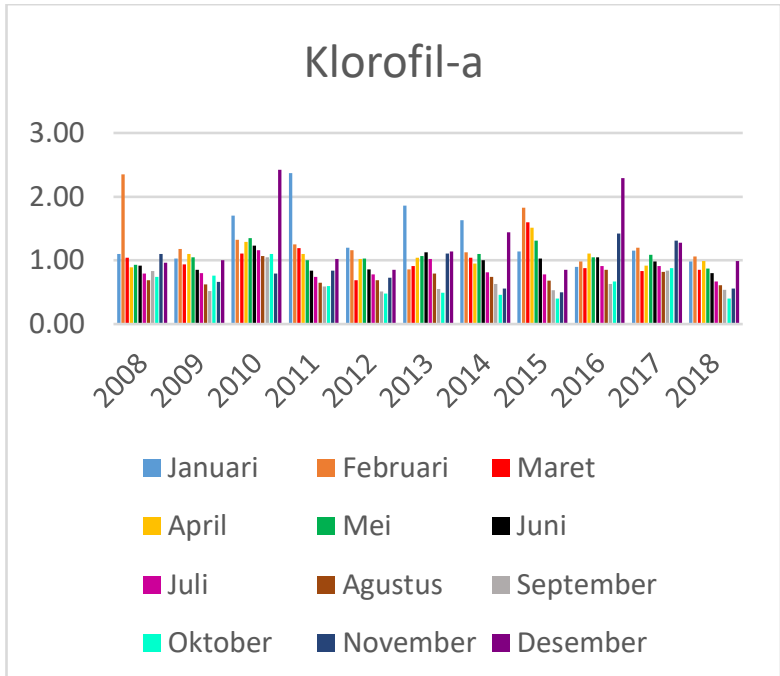

Figure. 2. Average chlorophyll-a concentration 2008-2018.

It can be seen that the highest value of chlorophyll-a concentration occurred in the west season together with the increasing rainfall (Figure 2 and Table 1), which concludes the peak of chlorophyll-a concentration from December to March associated with the rainfall rate [6]. According to Abd Rasyid [13], the chlorophyll-a concentration in the transition season from west season to east season was high, especially in the coastal region. Average chlorophyll-a concentration considered as high ranging between $0.90 \mathrm{Mb} / 13$ and 2.42 $\mathrm{Mb} / 13$ from November to February, while the chlorophyll-a attention from March to October was categorized as low, ranging from $0.40 \mathrm{Mb} / 13$ to 1.90 $\mathrm{Mb} / 13$. The fluctuation of chlorophyll-a concentration in a region is mainly influenced by the rainfall rate and current movement [14].

\subsubsection{Chlorophyll-a Distribution in FMA 712}




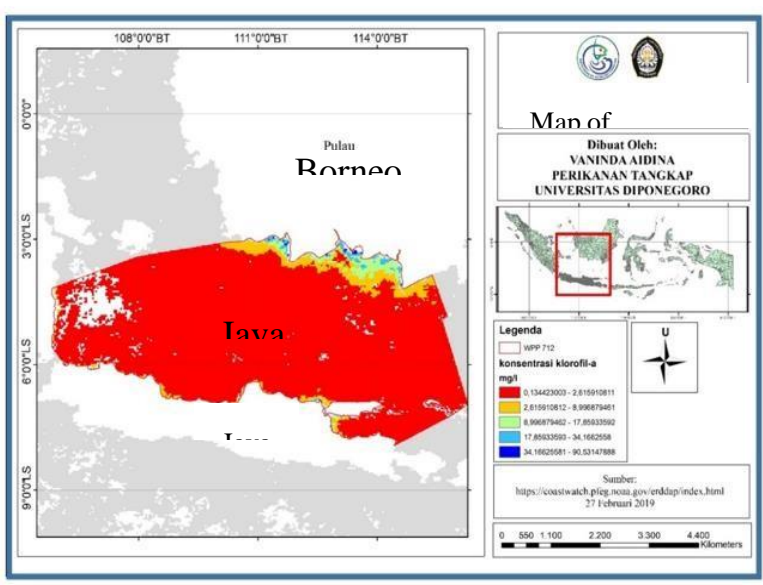

Figure 3. Map of chlorophyll-a distribution in FMA 712, June 2013

Based on the interpretation of satellite images in June 2013, the chlorophyll-a distribution spread out along the coastal both Borneo and Java Islands. The high contrast of chlorophyll-a concentration scattered in the northern part of FMA 712, while the slight attention in the southern region. This condition is influenced by the seasonal condition.

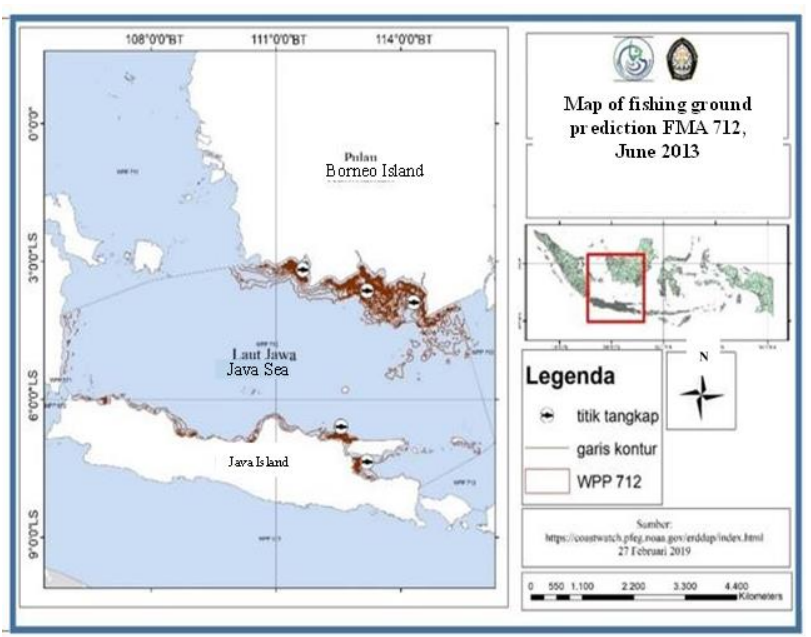

Figure 4. Map of fishing ground prediction FMA 712, June 2013

Phytoplankton is known as one parameter, which is essential in determining primary productivity in waters, while the distribution and its concentration correlated with the oceanographic condition [15]. Based on the chlorophyll-a distribution in FMA 712 as shown in Figure 4, it can be seen that the chlorophyll-a disperse more in the coastal region compared to the off-shore [10].

\subsubsection{Map of Fishing Ground Prediction Area}

Based on the results of the chlorophyll-a concentration map in the Java Sea in June 2013, it showed that the distribution of fish in the coastal region where the chlorophyll-a concentration was considered high. This condition is caused by the abundance of chlorophyll-a concentration associated with the water's food web. According to Nababan [14], chlorophyllattention showed a significant role in the tropical organism food web, which is known as a primary producer [16]. Several pelagic fish such as Sardinella lemurs (lemurs) and Sardinella Fimbriata (trembling) show a significant correlation with the rise of chlorophyll-attention in the region even though not directly influenced by sea surface temperature [10]

\section{Conclusion}

The highest chlorophyll-a concentration in the Java Sea (FMA 712) was found in the west season and the increased in rainfall during the moment, while the lowest concentration occurred in the east season (dry condition), mainly characterized as coastal area. Chlorophyll-a concentration is correlated to fishing grounds. Chlorophyll-a found in phytoplankton as the first producer is very influential for the distribution of small fish so that large fish are attracted to these waters.

\section{References}

1. E. Prianto, R. Puspasari, E. S. Kartamihardja, N. Zulfia, P. Rachmawati, D. Oktaviani, P. Penelitian, P. Perikanan, and K. Sumber Daya Ikan, in Prosiding Nasional Ikan Ke 8 (2015), pp. 29-40.

2. U. Chodrijah, T. Hidayat, and T. Noegroho, BAWAL Widya Riset Perikanan Tangkap 5, 167 (2016).

3. W. J. Ardiyani, B. H. Iskandar, and S. H. Wisudo, ALBACORE Jurnal Penelitian Perikanan Laut 3, 95 (2019).

4. I. Triarso, Saintek Perikanan: Indonesian Journal of Fisheries Science and Technology 8, (2012).

5. D. Zulhaniarta, fauziah Fauziyah, A. I. Sunaryo, and R. Aryawati, Maspari Journal : Marine Science Research 7, 9 (2015).

6. J. L. Gaol and B. Sadhotomo, Jurnal Penelitian Perikanan Indonesia 13, 201 (2017).

7. S. Siswanto and S. Suratno, International Journal of Remote Sensing and Earth Sciences (IJReSES) 5, 1 (2010).

8. E. Kharistiani and E. Aribowo, Jurnal Sarjana Teknik Informatika 1, 41 (2013).

9. I. Hermawan, A. Setiawan, and N. Pusparini, Jurnal Segara 13, 149 (2017).

10. E. Putra, J. L. Gaol, and V. P. Siregar, Jurnal Teknologi Perikanan Dan Kelautan 3, 1 (2012).

11. U. Tangke, Agrikan: Jurnal Agribisnis Perikanan 7, 74 (2014).

12. E. Prianto, R. Puspasari, D. Oktaviani, and A. Aisyah, Jurnal Kebijakan Perikanan Indonesia 8, 101 (2017).

13. R. F. Sihombing, R. Aryawati, and D. Hartoni, Maspari Journal 5, 34 (2013).

14. T. D. Kuswanto, M. L. Syamsuddin, and S. Sunarto, Jurnal Perikanan Kelautan 8, 1 (2017).

15. N. Fitriya and R. Aryawati, Maspari Journal: Marine Science Research 3, 1 (2011).

16. G. Winarso and E. Kurniawan, Jurnal Penginderaan Jauh Dan Pengolahan Data Citra Digital 11, (2014). 